\title{
Ideological Implications of Broadcasting Practice in Nigeria: From Pre and Post Independence Regulation to Deregulation
}

\author{
Olalekan Ganiyu Akashoro 1, Onjefu Okidu 2, Mikaila Ishola Ajaga 3 \\ 1. Department of Public Relations and Advertising, School of Communication, Lagos State University, Nigeria \\ 2. Department of Mass Communication, Caleb University, Nigeria \\ 3. Department of Broadcasting, School of Communication, Lagos State University, Nigeria
}

\begin{abstract}
The paper, within historical and ideological contexts, traces the development of the Nigerian broadcasting industry from a colonial initiative to a wholly public (government) enterprise and an admixture of public and private operations following deregulation.. Using, as framework, McQuail's suggested mass media normative responses to environmental social forces, an appraisal of how Nigerian broadcast media organizations have been responding normatively to the demands of component social forces within their operational environment leads the paper to conclude and recommend that the challenges of the dynamic social forces in the media environment impinging on the operations, creativity and potentials of media operatives should be given adequate attention by the industry's stakeholders.
\end{abstract}

Keywords: broadcasting, deregulation, mass media, McQuail, normative responses

\section{I.I Conceptual Framework}

\section{Introduction}

To broadcast is to disseminate information through mechanical means, simultaneously to a wide, diverse and heterogeneous audience made up individual within and outside a society. Broadcasting is indispensable in any society, permeating and fulfilling all individual, social, political and hedonic needs of people pivoted by the transfer of meaning - communication. The societal importance of broadcasting is underscored by Folarin (2000) when he defines the endeavour as:

"the planned provision of information, education and entertainment to large and heterogeneous audiences through the medium of radio or television" (P.35).

Broadcasting which involves radio and television broadcasting, as noted by Folarin (2000), expresses the assumption of "scattered dissemination to anonymous, undefined destinations made up of listeners and viewers" (Udeajah 2005).

This implies that, within a society, broadcasting operates not in a vacuum but as an element within a system comprising of mutually interactive, interdependent constituent parts or elements. This suggests that broadcasting, as an institution within a society, derives its functional relevance from its interaction or relationship with other societal elements, both within its organisational structure (i.e. operational managers, owners etc) and outside (i.e. sources, audiences, advertisers, government etc). Hence, logically, it can be posited that broadcasting, in any society, operates within an environment made up of dynamic, interactive internal and external forces.

This assertion is supported by Udeajah (2005) who, in adducing reasons for the development of broadcasting, mentions some of these external forces that impact on broadcasting contents:

"Broadcasting developed as a result of persistent experimentations of methods for central governments and centralized commercial organisations to communicate to a large number of people. Broadcast media have consistently maintained this objective of serving as the fastest method for political actors and business agents to communicate simultaneously to a heterogeneous listening and viewing public" (P:3-4).

This paper, therefore constitutes an attempt to examine in retrospect (i.e. historically), the evolution of broadcasting in Nigeria, from inception in 1935 to its present state of development at the turn of the 21 st ${ }^{\text {century }}$, precisely 2009. This historical overview, covering a period of 74 years precisely, is undertaken ideologically, in terms of an evaluation of the normative challenges faced by the different arms of the broadcasting institution in their interaction with environmental forces during the various stages of broadcasting development in Nigeria. And ideology, according to Cortean et al (2000:157), quoted by Udeajah (2005), "is a complicated term with different implications depending on the context in which it is used". Hence, putting it in specific contexts, ideology is used in the context of this paper to mean mass media norms; and ideological appraisal, contextually, refers to the normative responses of the mass media in managing relationships with social forces in their environment. 


\section{Review of Pertinent Literature}

McQuail (1992) posits that the media environment refers to (or is synonymous with) the field of social forces in which media organisations typically have to operate. McQuail expounds the media environment through a model which suggests that an organisation tries to meet conflicting demands, or expectations, in the face of obstacles and limitations. While Tunstall (1971) quoted by McQuail posits that the main goals of a newspaper or broadcast media organisation are mixed and even inconsistent; Gerbner (1989), also quoted by McQuail (1992) asserts that the main partners in the environment of the media, from the perspective of the model, vary in the degree of power or influence they can exercise.

From Gerbner's assertion, by implication, according to McQuail:

"the agencies with the most immediate power or leverage (especially owners, advertisers, sources and audience) are shown as closer to the media 'core' than investors, social institutions, suppliers, governments or pressure groups" (1992:82).McQuail (1992) further posits that a highly regulated industry, such as public broadcasting, may have government much 'closer' to the media organisation, and that in general the disposition of forces displayed in the model will vary according to industry type. To manage relationships with or threat coming from these environmental forces require the media organisation doing either of two things: "developing work routines which simplify the tasks and decision-making"; and "referring to a set of occupational or operating norms, which often connect with wider norms of conduct of public life" (McQuail 1992:83).

Also, according to McQuail (1992), it is not only the external relations of the media which give rise to conflicts with normative dimensions. Such conflicts also occur within organisations because of mixed, in some cases, barely compatible, goals. And similarly, internal conflicts about the goals of a media organisation is best understood from what Engwall (1978) as quoted by McQuail (1992:83) proposed as the three-fold division of work cultures comprising: management, editiorial, creative or writing people; and technical, design and production staff. Each of the three groups, according to Engwell, "is likely to have somewhat different goals, different normative priorities and different kinds of relationship with the various agencies in the media environment" (1992).

Of most importance and relevance to the discourse in this paper is how media establishments (broadcast media organisations - radio and television stations) respond normatively to pressures from social forces within their environment. Referring to this as normative responses to organizational pressures, McQuail (1992) submits that the types of relationship between the media organisation and each of the social forces or interactive elements in its environment (as represented in the model) determine the normative issues which recur in the day to day operations of a media organisation. These relationships include: relations with sources and selection decisions; relations with, or response to economic pressure and support; relations with the wider society-public interest or self interest; and relations with the audience (1992).

\subsection{Relations with Sources and Selection Decisions}

The problem, in this respect, as observed by Dimmick (1974) and Hirsch (1977) cited by McQuail (1992) is how to behave as "gatekeeper" under circumstances of varying ease or difficulty of obtaining material from sources. McQuail observes that there is usually a power imbalance between those seeking access to the media

"On the one hand, media are pressed to accept a large supply of ready-made content from well-organised and sometimes powerful sources (like government) departments, large firms, major social institutions). On the other hand, there are many sources and voices which are poor in resources, but not necessarily deserving of attention on grounds of relevance or significance" (1992:83).

And since, as Gans (1979), cited by McQuail (1992), further observes, apart from power imbalance between access-seeking media sources, the collection of news and the acquisition of material has widely varying costs to the organisation, the result may be a consequential bias, other thins being equal, towards "accepting content (thereby giving access) where content is both free and well organized to suit press needs"; and there may likely, be pressures on the media organisation" to avoid possible indirect offence to powerful interests (McQuail 1992:83).

This, as rightly noted by McQuail, makes the media to be continually faced with "a set of essentially normative dilemmas", a situation which becomes more sensitive or precarious in the relationship between the media and the state as well as the branches of government, with whom the media are potentially in a state of tension (in the process of performing their watch-dog role). In any society with predominantly state-controlled media, what government does is often significant, relevant and interesting and the media are consequently always dependent on government and its agencies for large and convenient supply of news. But in such a context, as rightly observed by McQuail (1992), the government usually has its own informational purposes "which go beyond the objective needs of the media or audience" (P. 84). In such an instance, according to McQuail (1992, citing Greber and Hohnson, 1961; Sigal 1973, 1986), "the media can be assimilated to those goals or sometimes compromised by a state of dependence and resulting compliance" (P:84). 
Furthermore, normative dilemma also arise in the relationship of the media with special interests and pressure groups, according to McQuail (1992:84) quoting Gandy (1982) "which seek to acquire (or to evade) publicity on their own terms; and such groups or interests may claim attention on the basis of legitimacy, appeals to altruism, or acknowledged general public esteem".

McQuail (1992) identifies a set of basic norms proposed by scholars to help media organisations to address normatively source related problems. These include that:

"- Media should not be influenced in what they do or do not publish primarily by fear of offence to the powerful or because of convenience, or of other rewards of collaboration;

- Competing claims for access should be assessed by the media mainly according to criteria of relevance to the audience or significance for society;

- Media should not unfairly penalize (e.g. by denial of, or by negative attention) the resources-poor, marginal or deviant groups and causes" (P:84)

\subsection{Response to Economic Pressure and Support}

McQuail (1992) identifies the main sources of media finance which can give rise to normative problems to include: those from third parties: (owners/or other paymasters) and would-be-advertisers or sponsors; and direct and indirect sponsorship. Income derived direct from consumers, McQuail contends, should not be regarded as "normatively problematic" because there is contractual agreement between the media organisation and the audience which is presumed to pay for what it gets and to get what it pays for.

According to Turow (1984) cited by McQuail (1992:84) "dependence on advertising revenue places media under a potential obligation to major advertisers". McQuail, quoting Meyer (1987) identifies proprietorial influence on content as well as political bias, especially towards business interests and rightwing government as major grounds for objection which may conflict with media claims to offer fully disinterested truth or independent opinion (1992).

In essence, McQuail also identifies a set of disparate normative propositions to help media organisations address problems having to do with relations with sources of media finance. These include that

"- Editorial judgments should not be subordinated to economic pressures, whether from proprietors, advertisers, sponsors, public funds or other financial sources (e.g. other business interest of a media firm).

- Where there is potential influence from financial source on content, this should be controlled and revealed; for example, by a clear separation of advertising from editorial content, by reporting sponsorship, by general openness about vested interests etc;

- Owners should not use their economic power on day-to-day basis, or in idiosyncratic and personally motivated way" (1992:85).

\subsection{Relations with the Wider Society}

According to McQuail (1992), media organisations, in most societies, usually attempt to meet and manage the many and varied demands of the larger society in two ways: through an equally diverse, selfregulatory and informal set of responses; and as a process of continuous response to the interests of their own audiences and to the requirements of clients and sources. Through this process, McQuail maintains, the media are attributed with the special obligation to satisfy customers and clients as efficiently as possible, from which wider benefits to society will flow" as guided by the 'hidden hand' of the media market" (1992:85).

McQuail identifies different research-based versions of the self-perceived social role of journalism or mass media in the society. These include:

I. As a neutral observer, transmitter, and interpreter of events of significance in society (the most commonly chosen version).

II. As a participant or advocate, involving the aim of engaging in political and social life and of having a purposeful influence on events. A variant of this is regarding the media as an altruistic element, an attribute which Gans, (1979) cited by McQuail (1999:85) refers to as "an impulse to speak up for society's victims, minorities and underdogs".

III. As a critic, adversary, watchdog of any sphere of public life.

IV. As a platform or forum for the diverse voices of society, allowing the expression both of varied opinions and of cultural streams. Considered in this way, the media constitute a public resource which allows society as a whole to speak for itself. McQuail regards this as a widespread view.

V. And as a responsible guardian which is sometimes adopted in matters of public order and morals, culture or personal conduct. This is a media role described by Blumler, (1969) cited by McQuail (1992:86) who expounds this further to mean "a commitment to public duty and traditional values over commercial success or popularity". 


\subsection{Relations with the Audience}

According to McQuail (1999), the media and their audiences, under condition of free choice and diverse supply, are usually considered unproblematic and self adjusting. This, McQuail contends, (citing Bauer 1958; Burns 1977 and Gans 1979) is an erroneous impression since evidence abounds that reveal that the audience is often viewed ambivalently by professional communicators, who have little time for most audience research and who construct images of the audience, according to their own self-images. This is despite the demands of the audience ideally providing the media performance yardstick (1992).

McQuail identifies the main problem facing media operatives to be the potential threat posed by the audience to their autonomy and, sometimes, to their professional standards. McQuail exemplifies such audiencerelated problem of media organisations calling for normative responses with situations arising "where pleasing the audience (for commercial reasons) may seem to be inconsistent with integrity and where professional norms may conflict with organizational policy" (1992:86). The mass media, McQuail affirms, resolve such problem by resorting to internal division of labour. McQuails (1992) explains further:

"Communicators can opt to serve a particular audience, or some goal of the organisation according to personal preference and sense of professional integrity, rather than to follow commercial goals" (P. 86).

\section{Research Questions}

In an attempt to appraise broadcasting evolution in Nigeria, this study shall seek answers to the following research questions:

1. Is there any difference or similarity between broadcasting operations in Nigeria before and after independence?

2. What has been the nature of the relationship between the Nigerian broadcast media system and forces within the broadcast media environment during the different periods of broadcasting evolution in Nigeria?

3. Is there any relationship between ownership of broadcast media organisations and choice of normative responses to demands of social forces within the broadcast media environment in Nigeria?

1. What have been the challenges of Nigerian broadcast media organisations or operators in meeting the demands of social forces within the broadcast media environment?

\section{Methodology}

The historical research method, qualitative and analytical, was adopted for this study. The major means of gathering data for this study are secondary sources - materials from scholarly books, scholarly articles and newspaper articles. Primary sources (such as diaries, original copies of broadcasting tapes-audio and visual being appraised etc) could not be procured for appraisal because of the length of time of the study $(1935-2008)$ which made procurement of primary sources, a daunting task. Information gathered were then analysed within the socio-political (prevailing governmental structure) socioeconomic (prevailing source of funding broadcasting operations) and the sociotemporal (the particular definite historical period in the country) contexts. From the analysis of data, inferences and conclusion were drawn and recommendations made.

\section{Findings}

This section of the paper discusses findings from the qualitative data gathered from secondary sources on the various periods in the evolution of contemporary broadcasting in Nigeria.

\subsection{Broadcasting in Colonial Nigeria}

This period is examined in the light of the following:

\subsubsection{The Rediffusion Era (NBS and NBC Years)}

The idea of broadcasting in Nigeria emanated from the United Kingdom when, in 1932, the British Broadcasting Corporation (BBC) launched the world's first regulatory schedule short wave programmes service (Udeajah 2005). The purpose, as observed by Mackay (1964) cited by Udeajah (2005:8) "was to develop some political culture and economic links between Britain and the English speaking countries". One of such stations was located in Lagos and turned out to be the "ears and the eyes" of both BBC and the British government. Perfection of the logistics of official launching of what could be regarded as model broadcasting in Nigeria took three years $(1932-1935)$. Government-sponsored broadcasting commenced in earnest in Nigeria with the official launching by the colonial government, of Nigeria's first known broadcasting system, the Rediffusion Broadcasting System (RBS) relayed through the Reddiffusion Box on December 1, 1935. Content-wise, the programme broadcast in the colony "consisted of a mixture of selected BBC materials and some colonial government programmes" (Udeajah 2005:8). And between 1935 and 1950, the BBC monitoring station in Lagos was developed into an extensive Radio Distribution Service (RDS) to cater for more parts of Nigeria, particularly those that were identified as densely populated centers (2005). The RDS was through subscription. 
The popularity of the radio distribution service among Nigerians led to the introduction of wireless broadcasting in Nigeria in 1951 through the establishment of the Nigerian Broadcasting Service (NBS) on the recommendation and approval of the National Legislative Council. The NBS, established with its own radio station in 1951, became the first public service broadcasting organisation to have existed in British colonial territory (Udeajah 2005). The ordinance establishing the NBS stipulated its functions as: (1) provision of educational services; and (2) provision of independent and impartial broadcasting service. Hence, between the 1940s and mid 1950s, the practice known as rediffusion became the principal mode of broadcasting in Nigeria.

Furthermore, the continued thirst for information by Nigerians besides the political, economic and social developments (Obazele 1996), and the increased struggle for political independence by the nationalists, led to the establishment of the Nigerian Broadcasting Corporation (NBC) in April 1957, three years before Nigeria's independence. The NBC was peculiar in its establishment for the reasons that: it was not a part of the civil service; it was not run by the government nor controlled by a ministry, although a minister was answerable for the corporation in the House of Representatives; and it was a non-profit making organisation (Obazele 1996).

Functionally, the establishing ordinance, the Nigerian Broadcasting Corporation Act of 1956 provided for the establishment of a corporation to take over the broadcasting services being rendered by the government, and stated the duties of the corporation as:

"(1) To provide, as a public service, independent and impartial broadcasting services by means of wireless telegraphy and by television for general reception within Nigeria;

(2) To provide services for general reception in counties and places outside Nigeria;

(3) To ensure that the services which it provides, when considered as a whole, reflect the unity of Nigeria as a federation, and at the same time give adequate expression to the culture, characteristic, affairs and opinions of the people of each region or part of the Federation" (Obazele 1996:146-147).

The establishment of the NBC paved the way for the debut of regional broadcasting in Nigeria, coming, as Obazele put its: "at a most trying point in the annals of Nigerian politics, when the Eastern and Western Regions of the country achieved self-government in the constitutional march towards independence and sovereignty" (1996:147).

From the media environmental context, the government element, represented by the Colonial British government, constituted the main social force or source of demand on, and constraint for Nigeria's earliest broadcasting experience. The British imperial government was the owner and sponsor of the radio distribution service meant, as observed by Makay (1964), cited by Udeajah (2005), to strengthen culturally, politically and economically the link between imperial Britain and the colonies. Situating the experience within the context of McQuail's observation on media's relations with sources, what obtained was that the Radio Distribution Service (RDS) depended solely on the colonial government and its agency, the BBC for its programming; since by nature of ownership, what the government did was seen as significant, relevant and interesting, and this reflected in the content of the RDS broadcast to the Nigerian audience.

Furthermore as noted in this study's literature review, none of the suggested alternative normative responses, as, articulated by McQuail (1992:84) could be applied to the RDS experience. For example, the suggestion that media should not be influenced in what they do or do not publish primarily by fear of offence to the powerful, would obviously be impossible or difficult to apply under the RDS experience. The same foregoing observation applies to the government-sponsored Nigerian Broadcasting Service established in 1951.

\subsubsection{The Regional Broadcasting Era}

The idea of regional broadcasting predated the establishment of the NBC in 1957. It was constitutionally sanctioned through efforts of the nationalists in the McPherson constitution in 1954. The constitutional provision permitted regional governments to establish their own broadcast stations. Actual regional broadcasting did not commence until 1959 when, in response to the constitutional provisions of 1954 (the Macpherson constitution), the Western Region established the Western Nigeria Radio-vision service and commissioned the Western Nigeria Television (WNTV). As Udeajah puts it:

"This is the development that gave birth to the first television station in the country in 1959; it all started in the Western Region, precisely in Ibadan" (2005:10)

Following the establishment of the first regional TV station in Nigeria, its radio counterpart was established under the auspices of the Western Nigerian Broadcasting Service (WNBS). This was followed by the establishment of more broadcasting stations in other regions of Nigeria. The Eastern Nigeria Broadcasting Service (ENBS) emerged in 1960, "under the pressing need to air messages of political significant" (2005:10). And in 1962, the Northern Region established the Broadcasting Company of Northern Nigeria (BCNN) which set up the Radio Kaduna Television (RKTV) the same year. The essence of the creation of regional broadcasting institutions by the regional governments was to promote their political aspirations and this reflected in the programming of these broadcast stations. 
Similarly, from the media environmental context, the government element, represented by the regional governments of Western, Eastern and Northern Nigeria, constituted the main social force or source of demand on and constraint for Nigeria's first experience in regional broadcasting. Since the essence of establishing regional broadcasting institutions was "to feather the political nest of the owner-region, which provided subsidy for media operations" (Udeajah 2005), their programmings were exclusively customised to reflect, serve, and propagate the political aspirations of the regional governments. Applying this to McQuail's observation on media's relations with sources, the regional stations must necessarily see (and they actually saw) the regional governments' programmes, activities and policies as "significant, relevant and interesting", and this actually reflected in their programming.

Similarly, the NBC owned its existence and allegiance to the constitutional instrument that set it up (the NBC Act of 1956) and to the electorate (nationally and regionally) to whom its programming contents were directed. Hence, it had to contend with the Federal and regional governments as well as the electorate (representing the audience of its programming) as the principal social forces in its media environment. These were the elements, during the early years of the NBC's existence that constituted sources of demand and constraint on the organisation.

Furthermore, none of McQuails suggested alternative normative responses would be feasible under the condition in which the early regional broadcast media organisations operated. These regional broadcast media organisations could not, but be influenced in their programming and sources of their programming contents by the regional aspirations of the governments that established and funded them.

\subsection{Broadcasting in Post Independence Nigeria}

This period is examined in the light of the following:

\subsubsection{Broadcasting in the First Republic (1963 - 1966)}

Following the trail of the regional governments which had established television and radio stations, the federal government, "as a matter of political necessity" (Udeajah 2005), established the Nigerian Television Service (NTS) to complement its pioneer radio station (NBS) which on October 6, 1956, had been renamed Nigerian Broadcasting Corporation (NBC). By the advent of Nigeria's First Republic in 1963, from independence in 1960, the regionalisation was maintained, with each region having and managing its broadcasting establishment; while the federal government continued to manage the broadcasting institution inherited before independence (The RDS, NBS and later NBC) as well as the newly created NTS. The peculiarity of broadcasting during Nigeria's First Republic is aptly presented by Udeajah (2005) as follows:

"The organisation of broadcasting during the civilian rule in the First Republic was the priviledged responsibility of the political elite in power. All the broadcasting systems (radio and TV) were government owned and controlled. Lagos city, for example, operated its radio system that largely served federal government interests. Similar situations were obtained in the regions" (P. 48)

Also, the NBC, throughout the First Republic, operated a three-tier programming system covering national, regional and provincial interests. The NBC was broadcasting nationally and concurrently with regional stations, an arrangement which lasted until 1966 (2005).

From the medial environmental context, operators of the broadcasting system during the First Republic contended with the government as the principal social force or source of demand on, or constant for both the federal and regional broadcasting organisations. The reality of the potential of broadcasting as a means of raising political consciousness and sensitizing the populace towards particular interests, made the government element to be the domineering social force. Other environmental elements in contention, and with whom the broadcasting organisations had to relate, were advertisers, the general audience and the political institutions (the political parties from the various regions and at the Centre (Action Group, NPC, UPGA, NNDP, NCNC, NEPU etc).

Going by McQuail's submission on the media's relations with sources, the First Republic broadcast media organisations, federal and regional, promoted their owners' interests and derived the bulk of their programming contents from government sources including government agencies, ministries etc. And as McQuail has noted (1992:84), these broadcasting establishments were assimilated to the goals of their owners, and on their own, had to compromise because of their sole dependence financially on these governments, apart from other minor sources of funding. By implication, adoption of McQuail's suggested source-related normative responses by these organisations was not practicable in the circumstance.

Also, in terms of relations with the wider society, the broadcast media during the First Republic promoted, not public interest, but majorly, the self-interests of their owners. Neither could they be considered as neutral observer, public advocate, guardian, critic, adversary or watch-dog; nor did they provide a forum or platform for diverse voices of society to be heard. 


\subsubsection{Broadcasting during the Period of the Nigerian Civil War (1967 - 1970)}

The Nigerian civil war which began on July 6, 1967 and lasted till 1970 was fought between the government of the Federal Republic of Nigeria headed by Colonel Yakubu Gowon on one side and the people of the Eastern region under the auspices of the Republic of Biafra, headed by the then Governor of that region, Lt. Co. Odumegwu Ojukwu.

All the broadcast media organisations during the war still maintained the status of government owned institutions. They also vehemently promoted the interests of their owners. While the broadcast media from the Eastern part promoted the cause of Biafra; and which Udeajah (2005) describes as "Broadcasting for Survival". On the other hand, broadcast media owned by other regions and the Federal government championed the Federal cause, and which Udeajah (2005) also christens - "Broadcasting to keep Nigeria One". Painting the scenario of the broadcasting system during the Nigerian civil war, Udeajah (2005) writes:

"In short, the broadcasting stations in the country were aligned into blocks as media practitioners spread propaganda in favour of their regional inclinations. Teaming up with the political elite, broadcasters took sides with their regions during the series of conferences that were organized to determine the supposedly new constitutional propositions for the country. With the declaration of the Republic of Biafra and the subsequent outbreak of war, therefore, there emerged a series of slogans from the opposing camps. For instance, Radio Biafra affirmed as follows: 'The price of Liberty, external vigilance. Biafrans be vigilant!' Through constant repetition, citizens of the Biafran camp soon learnt the appropriate slogan by heart ... Needless to state, in-that context, that the broadcast media continued their political education, even in such a war situation" (P:79).

From the media environment point of view, again, the recurring dominant social force, constituting a source of demand on, and constraint for the war years broadcast media, was the government element. The federal and regional broadcast media, through out the civil war period was, as earlier stated, preoccupied with disseminating war propaganda materials out of compliance and relegating other programming contents to the background.

In terms of normative responses, the circumstances in which the media organisations operated during the civil war years made adoption of McQuail's suggested normative responses to pressure from environmental forces, particularly the various governments, by these organisations impracticable. This was so for the reasons that the broadcast media, like before, were influenced in their programming by their government owners out of compliance or fear of offence to these owners; editorial judgments were subordinated to economic and political pressures from the various governments; there was potential and actual influence on content (i.e. programming) by the governments as the financial source which could not be controlled by these media; the owners of these media (i.e. the governments) used their economic and political power on day-to-day basis, and especially in personally motivated ways; these media could not be described as neutral observers for transmitting and interpreting events of societal significance according to the wishes of their owners; and these media never acted as advocates of peace nor did they provide a platform for diverse voices of society.

\subsubsection{Broadcasting during the Post Civil War Period (1970 - 1979)}

This period is examined from the perspective of three regimes: the Gowon, Muhammed and Obasanjo administrations.

\subsubsection{Broadcasting and the Post-war Government of General Yabuku Gowon (1970 - 1975)}

Broadcasting system during the remaining part of General Yakubu Gowon's administration after the end of civil war hostilities in 1970 helped in propagating the federal government's post war policy of Rehabilitation, Reconstruction and Reconciliation. The broadcast media were particularly instrumental to the propagation of the essence, the ideals and the rudiments of the second national development plan $(1970-1974)$. Placing the media, particularly the broadcast media, within the context of the plan, Udeajah (2005) observes that the second national development plan:

"envisioned to provide, among other things, viable media of information to enhance the programmes of fostering reconciliation after the civil war and to mobilize support for effective national development. In the process, balanced information about the country was to be provided" (p.104).

Examined from the media environmental context, the broadcast media during the post war Gowon military administration had to contend with many social forces including the dominant government element as well as the audience (that needed to be sensitized towards appreciating the essence of the second national development plan), other sources (individuals given access to debate and contribute to the implementation of the second national development plan) and pressure groups (the professional associations to whom the broadcast stations are affiliated - SOBON, TON and BON).

In terms of normative responses to environmental pressures, the broadcast media, because of their peculiar situation, operated at variance with most of McQuail's suggested normative responses. The broadcast media's programming contents were influenced by their government owners out of compliance; editorial 
judgment (i.e. programming) was subordinated to economic pressures from the governments as principal financial sources; and government as owners of these media used their economic power daily to regiment programming of their media organisations. On the positive side, the broadcast media gave access to non government sources on the strength of their significance for society and provided a forum for diverse voices of many Nigerians or public affairs critics to be heard, particularly on the second national development plan.

\subsubsection{Broadcasting during the General Murtala Muhammed Military Administration (1875 - 1976)}

Nigeria's third military coup of July 29, 1976 ushered in the regime of Brigadier Murtala Mohammed. In Febuary 1976, the Muhammed Administration increased the number of states in Nigeria from 12 to 19, few days before the regime was abruptly terminated through a bloody coup led by Lt. Col. Buka Suka Dimka on Februay13, 1976 (Udeajah 2005).

Characteristics and operations of the broadcasting system while this short-lived regime lasted include the following:

I. Ownership of state-owned broadcast stations increased as number of states was increased from 12 to 19 Udeajah (2005) notes:

"In the long run, the increase in the number of states implied corresponding increase in the number of broadcast media establishments to cater for the communication needs of the emerging states" (P:111)

II. The broadcasting system was completely subordinated to the status quo. The broadcast media propagated, defended and rationalized the policies and actions of the administration to the populace. These include: imposing uniform policies on the federal structure, undertaking a massive purge of the Nigerian Civil Service; increasing the number of status from 12 to 19 , removing governors from the supreme military council, creating for them a third-tier council of states; and removing the national capital from the coastal city of Lagos to Abuja, Nigeria's heartland (Udeajah 2005).

III. The Broadcasting system particularly federal radio broadcasting system was barred from accepting advertisements and getting involved in commercial broadcasting. According to Uche (1989:45):

"The military argument was that it (radio broadcasting) was developed as a public utility and as such it should aid the government in its development campaigns. It was feared that permission to go commercial might affect the policies and orientation of the management".

Situated within the context of media environment, the broadcast media, during the Mohammed regime, as with previous military regime of General Gowon, had the governments at the federal and state levels, to contend with as the dominant social force, relegating other forces to the background. As before, the broadcast media operated in an atmosphere that made it impossible for them to adopt McQuail's suggested normative responses. This was for the same reasons given for previous regimes; the basic reason being that the media operated principally as government's mouth organs or agents of public communication.

\subsubsection{Broadcasting during the General Olusegun Obasanjo Military Administration (1976 - 1979)}

General Olusegun Obasanjo, as a Brigadier, came to power, on February 13, 1976 as a successor to the late General Murtala Mohammed.

Features and operations of the broadcasting system during the Obasanjo Military administration include:

I. The broadcast media suffered massive withdrawal of experienced broadcast practitioners and the deployment to these media organisation of inexperienced hands, and this negatively affected the media's professional performance.

II. The Broadcast media constituted federal government's machinery or agents for the promotion and propagation of its agricultural project - Operation Feed the Nation (OFN).

According to Udeajah (2005), from the inception of the OFM programme:

"the Nigerian broadcast media took up the responsibility of mobilizing the populace. Both radio and television played leading roles in the campaign to grow more food". (P:115)

III. The Broadcast industry witnessed far-reaching restructuring by the Obasanjo administration. On the nature of these changes, Udeajah (2005) writes:

"The military government of General Obasanjo took over all radio and television stations in the country, promulgated Decree No. 24 of March 1977 that created the NTA, introduced networking of news, and embarked on mass recruitment of broadcast personnel to ensure that the system was kept in constant operation". (P:130)

The decree establishing the NTA which actually took retrospective effect from April 1976 when the federal government began funding the then existing television stations, empowered the organisation to exclusively operate television services in the country. This meant that no other broadcasting authority or individual could operate television broadcasting (2005).

IV. Broadcasting operations got a boost during the Second World Festival of Black and African Arts and Culture, FESTAC '77. The NTA and FRCN, according to Udeajah (2005) "were supported to enable them perform and ensure that they remained loyal and docile to the military government" (P:130). 
V. The broadcast media constituted federal government's agents for mass mobilization on its transition to civil rule programme. Udeajah (2005) aptly captures the operations of the broadcast media in this respect:

"The broadcast practitioners manifested some general restraints in their selection of programmes transmitted during the period of transition to democratic rule. It was feared in various levels that the slightest deviation from the norm would meet with devastating blow from the military government that structured the transitional activities" (P:121).

Within the context of media environment, the broadcast media had to content with various social forces, the most dominant of which was the federal government which exercised absolute control over the broadcast media in terms of ownership and operations. Other forces were the political transition institutions such as the political parties and candidates, FEDECO etc and pressure groups such as professional media associations like BON, NAN, FRCN etc, and the media audience represented by the electorate.

In terms of the broadcast media relations with these forces, the media operated under conditions similar to what obtained during previous regimes: they were subordinated to the status quo, hence their programming, to a large extent, reflected the interests of the government in power. But to a lesser extent, the broadcast media provided a platform for the expression of varied political views and opinions: they were actively involved, through coverage, in the electioneering campaigns of the political parties.

\subsection{The Broadcasting System: From the Second to the Fourth Republic}

This period is examined form the following perspectives.

\subsubsection{Broadcasting during the Second Republic (1979 - 1983)}

The second republic which commenced on October 1, 1979 signalled the return to civilian government. The administration was headed by Alhaji Shehu Shagari who turned out to be Nigeria's first executive president. Characteristics and operations of the broadcast media during this period include:

I. The broadcast media, despite the euphoria on the country's second attempt at democratic governance, operated in an autocratic setting. There was complete federal and state government ownership and monopoly of broadcast stations.

Government censorship was more stringent under the regime than in preceding military regimes. This view is confirmed by Ogunsuji (1989), cited by Udeajah (2005), who observed that:

"most newspapers and broadcast stations owned by government hardly carried negative or bad news concerning government activities. Media whose political learning favoured the governmental patronage through advertising avoided all damaging stories on government policies or activities. Rather, the editors tended to trim, kill, slant or display a reporter's story in such a way as to support the official version. Thus the Nigerian civilian government, at the federal and state levels, manipulated the media practitioners into cooperating in bending and blending public opinion to the taste of the political elite" (Udeajah 2005:137).

II. The broadcast media, despite being government owned, became commercially-oriented: they complemented government funding with revenue derived from selling of advertising spots to meet operational costs. Hence, they had to contend also with getting advertising patronage.

III. The broadcast media, particularly those from the states, had to contend with executive discrimination. The form of discrimination was as captured by Udeajah (2005:138)

“... the government of Shagari went even further in 1983 when it started rationing newsprint importation in order to deal with what was perceived as the opposition press and broadcast establishments".

The broadcast media, from the media environment context had to grapple with pressures from virulent social forces, the most dominant of which still remained the government force - federal and state governments. Other social forces included political institutions like the political parties, FEDECO etc, advertisers (government and private), pressure groups (professional associations like the NLC, BON etc) and other sources (political elites, social critics etc). Relating with these forces normatively had implications for McQuail's suggested normative responses. Principally, the broadcast media, being government controlled, depended largely on the government and its agencies for most of its programming content. The media compromised their own individual interests or editorial judgements and acceded to promoting government interests out of compliance. The media gave virtually little or no access to dissenting voices or views, especially those that were political. And also, the media never pretended to act as a neutral observer but provided information that was slanted to suit particular interests. 


\subsubsection{The Broadcasting System during the General Muhammadu Buhari Military Administration 1984 -} 1985)

The coup of December 31, 1984 spearheaded by Major General Muhammadu Buhari terminated the second tenure of the civilian administration of Alhaji Shehu Shagari, thereby ending Nigeria's second republic. The Buhari administration came to power formally on January 1, 1984.

Characteristics and operations of the broadcasting system during the regime include.

I. As before, funding, ownership and operational control of the broadcast media rested with the military government at the federal and state levels.

II. The broadcast media actually contributed to the propagation of government's developmental or charactermoulding programme - War Against Indiscipline (WAI). According to Udeajah (2005):

"Though short-lived, the Buhari administration left its mark on the broadcast industry. Its campaigns of War Against Indiscipline (WAI) were fully run by radio and television Jingles and commercials on the queuing culture, one-after-the-other banking and monitoring and environmental sanitation were all carried by the radio and television station systems ..." (P:155).

III. The broadcast media witnessed staff rationalisation that was unprecedented. Udeajah (2005:156) provides an account of the rationalisation:

"Actually, the year 1986 was a very difficult one for the broadcast practitioners in Nigeria. A government white paper was released on the rationalisation of the services of the NTA. The stations were directed to seek alternative sources of revenue through a revision of their advertisement policy. As a result of this, some public interest-oriented programmes failed to get sponsorship and eventually died off. The broadcast industry thus became subject to the dictates of advertisers who determined the air space and time".

IV. The broadcast media witnessed an increase in the numerical strength of broadcast stations.

According to statistics, (Udeajah 2005), by the end of the regime in 1985, all state capitals had each station too. And apart from the federal stations, about 11 states had established their own television stations. From the media environmental context, the broadcast media also contented with the federal and state governments as the dominant social force; while because of governments rationalisation policy, advertisers constituted another formidable social force.

In relating with these social forces normatively, the broadcast media had no option but to do the bidding of the ruling authority - the government. And as noted by McQuail (1992:84), though dependence on advertising revenue, as a result of rationalisation, placed the broadcast media under a potential obligation to major advertisers, they (the broadcast media) had to balance this with the policies, interests etc of their owners the governments through the types of advertisements and programme run.

\subsubsection{The Broadcasting System and the General Ibrahim Babangida Military Administration (1985 -} 1993)

Major-General Ibrahim Babangida took over the leadership of the Nigerian government in a palace coup on August 27, 1985.

Characteristics and operations of the broadcasting system during the Babangida administration include:

I. The numerical strength of state owned broadcast media increased as eleven additional states were created, two in 1987 (Akwa-Ibom and Katsina States) and additional nine in 1991 (Abia, Taraba, Jigawa, Kebbi, Delta, Osun, Anambra, Yobe and Kogi States). The creation of the new states led to the establishment of more broadcasting establishments in the country.

II. The broadcasting system witnessed an upsurge in political broadcasting. The reason for this was as presented by Udeajah (2005):

"The state creation exercise unleashed another era of political broadcasting. Each of the new states wanted to air its views to its people in its own way and to compete with the mother-state in terms of ownership and operations" (P:160).

III. The broadcasting system witnessed increase in the production of locally-produced home movies and programmes as a result of increase in number of trained personnel. (Udeajah 2005).

IV. The broadcasting system, early in the regime, witnessed heightened tempo in the scrambling for and partition of broadcast assets and liabilities between the new states and their mother states. The imbroglio over broadcast asset sharing, as noted by Udeajah, was anchored on political propensities.

"The urge to have its own broadcast organ was engineered by political prestige and pride among the new states. They wanted to be like their counterparts and even felt an air of superiority over their mother states. It all depended on how they developed their own electronic media organisations". (2005:161).

IV. The broadcast media, as with previous regimes, operated as governments' agent of public and political communication. The broadcast media were actively involved in the propagation and promotion of governments' developmental and political programmes. These include: championing the cause of the Directorate for Food, Road and Rural Infrastructural (DFRRI); promoting the Better Life for Rural Women programme, giving 
adequate publicity to the programme and activities of the federal government established Mass Mobilization for Social Justice and Economic Recovery (MAMSER), the IMF Loan Controversy, SAP and propagating the federal government's initiated programme of transition to civil government, including the activities of the institutions put in place to effect the programme (Udeajah, 2005).

V. The broadcast media, echoing their antecedents, subordinated themselves to the status quo out of compliance.

VI. The Broadcasting system witnessed, first time, initiation by the regime and eventual Liberalization of broadcasting which introduced private ownership of the electronic media.

VII. The broadcast media participated actively in the unfolding political transition process, including: providing adequate coverage for the activities of the two eventually sanctioned political parties - SDP and NRC, including their rallies, conferences, and also providing a platform for an interactive session among political candidates); offering spaces for political advertisements; providing adequate coverage for the elections, including the controversial June 12, 1993 presidential elections and the post election events, controversies etc which led to the annulment of the presidential election results and the eventual stepping-aside of president Babangida and exit of his administration on August 26, 1993.

The broadcasts media, from the perspective of the media environment, had many social forces to contend with. And like the preceeding regimes, the most dominant of these forces was the government element. The federal and state governments, both military and civilian. Other forces that engaged the attention of the broadcast media include political institutions, political parties, NEC, etc; advertisers corporate brand/service, and political advertisers; social institutions - advocacy organisations (NGOs), social critics, public affairs commentators etc; pressure groups - professional associations, organisations etc - BON, ADVAN, NIPR, APCON, OAAN etc, and the audience - the citizenry, the electorate.

In terms of normative responses, going by McQuail's suggested alternatives, the broadcast media operated in similar circumstances as in the previous regimes. In relating with the governments as their principal news sources, the broadcast media had no option, other than to regard activities, programmes and policies of their major financier - the government, as significant, relevant and interesting, even if in reality, this is not so. In effect, the media were influenced in what they broadcast out of fear of offending the government; programming decisions of the broadcast media were subordinated to economic pressures from advertisers, particularly political advertisers, and the broadcast media did not, in any way act like a neutral observer, but rather, presented themselves as mouth pieces of vested interests.

\subsection{The Era of Deregulated Broadcasting System (1994 - 2008)}

Decree No. 38 of August 24,1992 as promulgated by the Babangida Administration ushered in the era of deregulated broadcasting in Nigeria. It permitted private ownership of the broadcast media, unlike exclusive government ownership of same that had prevailed since the advent of broadcasting in Nigeria. Udeajah puts it succinctly:

"Liberalisation of broadcasting was a landmark of achievement in the Babangida administration. The General, by authorizing private ownership of the broadcast media, loosened the tight rope of government monopoly on the electronic media. Thus, he united the knot that was tied in the early, years of Radio Redistribution Services" (2005:164).

\section{Characteristics and Operations of the Nigerian Broadcasting System Since Deregulation}

I. The Nigerian broadcast media, until formal operation of private broadcasting in 1995, continued to act as government propaganda agents or megaphones, with their programming still subordinated to and controlled by the government at the federal and state levels. This was despite the existence of the NBC and provisions of the Code.

II. The deregulated Nigerian broadcast media, especially during the last years of successive military administrations that transited Nigeria into the Fourth Republic, still witnessed government interference in and control of broadcasting operations by private broadcast media operators. The NBC itself, through its regulatory powers, can reasonably be perceived as an instrument of government's interference and control of the operations of the Nigerian broadcasting system, particularly the private broadcasting sub-system. This is exemplified by the stoppage of Raypower $100 \mathrm{FM}$ from hooking unto the $\mathrm{BBC}$ news programme effected by NBC. Under the directive of the Federal Military Government, MBC ordered the station to stop the "transmission of all unedited foreign news programmes" (Media Rights Monitor 1997, cited by Udeajah, 2005 ).

III. The Nigerian broadcasting system has been witnessing the pervasive and overburdening influence of the NBC's regulatory and monitoring activities on their operations. The NBC monitors the country's existing 244 television stations (as at 2003) distributed as follows: federal government owned NTA stations 148, state government TV stations 64, and private TV stations 32 (Akinfeleye 2003:44) 
It also monitors Nigeria's existing 95 radio stations (as at 2003) distributed as follows: Federal government owned radio stations 37 (comprising 5 FRCN Network Stations located in Lagos, Ibadan, Enugu, kaduna and Abuja and which are both FM and AM stations, as well as 32 New FM Stations), state radio stations 36, and private radio stations 22 . The 22 private radio stations, according to Akinfeleye (2003:45) include four specialized private radio stations which are Atlantic FM station for French programmes, spectrum FM stations - for Hard News, BRILLA FM - mainly for sports and UNILAG FM radio station - for education and academic programmes.

Apart from this monitory role, the NBC currently grants operating licences to the private sector as well as state government owned broadcasting corporations.

IV. The Nigerian broadcast media, during the administration of General Sani Abacha, did little to change their long earned image of promoting the status quo, despite the supposed independence of the private broadcasting sub-section. Most of the private radio and TV stations available as at then could not be openly critical of the Abacha administration because of possible destructive reprisal from the government. They therefore, swallowed their pride and followed their government owned counterparts to promote government policies and programmes at the expense of objective and critical reporting.

V. The broadcast media witnessed a return of guerilla (or illegal) broadcasting especially during the Abacha administration. One of such stations was Radio Democrat International Nigeria (RDIN) floated and funded by prodemocracy groups and later renamed Radio Kudirat in a public announcement made by Professor Wole Shoyinka in June 1997, in honour of Kudirat Abiola, wife of the then detained M.K.O. Abiola, who was assassinated by government agents on June 4, 1996. Radio Kudirat closed transmission on December 31, 1998. While it lasted, it operated on short wave band. (Udeajah 2005).

Another guerrilla broadcasting was perpuated by another private station, Radio Freedom Frequency (RFF) which hit the airwaves several times between June and August 1995. The RFM operated on Frequency Modulation (FM).

VI. The broadcast media were actively involved in the propagation and promotion of the General Abubakar organized short political transition programme which eventually led to the swearing in of General Olusegun Obasanjo (rtd) as the Executive President of the Federal Republic of Nigeria and ushered in Nigeria's Fourth Republic on May 29, 1999. The broadcast media facilitated the political transition process promoting and disseminating information to Nigerians, particularly the electorate, on the activities of the major stakeholders in the transition.

More specifically, the broadcast media, particularly the privately owned, assisted in enhancing personal influence and thereby achieving political power for individuals, political institution of interest to them, either through ownership, connection with ownership or through business patronage or association. Udeajah (2005) observes:

"During the 1999 politics, the role of public service broadcasting became evident in reporting and interpreting political events; defining trends in the transition process and in educating the population politically through news and current affairs programmes. The private broadcasting stations became preoccupied with projecting the personalities of candidates through political advertising. This enabled some candidates of such political image-promoting adventure to gain some competitive advantage" (P:205).

VII. The deregulated Nigerian broadcasting industry witnessed many challenges accelerated and intensified by the succeeding civilian administrations of General Olusegun Obasanjo. These challenges were consequences of the amendment to the NBC decree which brought sweeping changes to broadcasting operations in Nigeria.

VII. The Nigerian broadcasting system, after deregulation, has witnessed increased phonography in broadcast programming of most stations, particularly private ones. Enemaku (2003) captures this dysfunctional use of the power of broadcasting by the broadcast media:

"In a bid to increase their audience, many broadcasting stations transmit programmes that appeal to the sensual instincts of the public. Sex appeal is capitalized upon, and inspite of the regulations of both the National Broadcasting Commission (NBC) and the National Films and Video Censors Board (NFVCB) many violent, erotic and generally morally perverse programmes are transmitted. In recent times, many Nigerians, including religious leaders and others have vehemently criticized broadcasting stations for the nudify and violence transmitted on the stations" (P:59-60).

IX. The Nigerian broadcast media are gradually waking to the operational challenges posed by advanced technology. Like in the advanced world, many broadcast stations, both government and private, have acquired and have started broadcasting with modern digital equipments or facilities in order to enhance their performance or delivery rating among their listenership and viewership. A recent example is DAARSAT, a multi-channel digital satellite transmission facility launched in November 2008 by DAAR Communications, operators of African Independence Television (AIT) and Ray Power FM. With this facility, over 50 channels of different broadcasting contents are available to prospective subscribers. This is 
a plus for the broadcasting industry in Nigeria. This has also increased for the broadcast media advertising patronage: the use of state-of-the art equipment brings about better quality delivery and reception as well as better mileage in terms of coverage, all of which are attractions or motivations for advertisers.

The Nigerian broadcast media of the current deregulation dispensation, appraised within the context of the media environment, have more social forces to content with than those of the pre-deregulation era. But despite deregulation, and the sanctioning of private broadcasting to cater for wider interests, the dominant social force, like before, still remain the government. The government still indirectly controls the broadcasting system through the NBC which regulates the broadcast media as dictated by government through provisions of the NBC code. Other contending forces or elements that put pressures on the broadcast media, and which necessitates normative responses as proactive and reactive measures include: advertisers (brand/service, institutional and individual); institutional political advertisers or spot buyers who are also enticed into programme sponsorship; owners of the broadcast stations, both private broadcast operators who demand patriotism and loyalty of the station's programming to their interests and allies, and the government-owners that demand nothing less than total allegiance of their stations' programming to their interests, expressed through policies, actions and programmes; other sources of programming contents such as local and international broadcasting networks and programme syndication companies, independent production companies or producers, both local and international, wire services or local (NAN) and foreign news agencies (e.g. Renters, AP, UPI etc) and affiliated broadcasting stations (e.g. TV Africa); the general audience (viewership and listernership) who want their interests met and needs fulfilled through the stations' programming; social institutions like the NGOs who want their interests and causes publicized, the religious organisations who want their activities publicized; and some particularly the orthodox denominations or sects, who also advocate for the removal or non exposure of certain aspects of broadcast programming; political institutions such as political parties, political elites, candidates who want their political interests promoted through the stations, electoral institutions like INEC whose workings and activities are expected to be made known, clarified and interpreted to the electorates and government established agencies like the National Orientation Agency which constitute an institutional advertiser to broadcast stations; investors such as shareholders in some of the stations who may want to influence certain aspects of such stations' programming to suit their interests; and pressure groups such as relevant professional organisations like BON, APCON, AAAN, SWAN, ADVAN etc whose activities impact on the operation of the broadcast stations; as well as labour unions and civil society or human rights organisations like PRONACO, CLO etc who require and strive to have their agitations and causes given adequate publicity by the broadcast stations.

In terms of maintaining relations with these social forces, the broadcast media in Nigeria's over 16 years deregulated broadcasting industry, particularly those in the private broadcasting sub sector, should expectedly be able to respond normatively in accordance with McQuail's normative propositions. Even in the era of deregulation, McQuail's submission on government-media relations, in terms of news sourcing, holds true for the broadcast media. Despite private broadcast operations, both set of broadcast media on the two sides of the divide (private and public), still see government activities, programmes etc as "significant, relevant and interesting" and as such, contemporary Nigerian broadcast media still depend on the government and its agencies for "large and convenient supplies of news" (McQuail 1992). However, extent of dependence on the government sources would depend on the status of the broadcast station in question, whether privately owned or government establishment. Also, the government-owned stations, unlike their private counterparts, till date, are actually assimilated to the goals or interests of the government which they reflect in their programming. These media compromise the objective needs of their audience, and even themselves, and accede to government interest out of compliance or dependence on government for funding or subvention to meet their operational costs.

\section{Emerging Hypotheses (Observations)}

From an evaluation of the operations of contemporary Nigerian broadcast media on the basis of McQuail's normative propositions, the following are discernible.

1. While government owned media are still influenced in what they broadcast or do not broadcast primarily by fear of offence to the government, private broadcast media are not. But private broadcast media are influenced because of rewards of collaboration. An example is the affiliation of some of the broadcast stations with TV Africa (e.g. Channels TV) which influences their programming.

2. While the private broadcast media are more likely to evaluate competing claims for access by potential sources mostly on the basis of relevance to the audience or significance for society, the government-owned broadcast media would most likely evaluate such claims on the basis of what is of interest to the government to whom they hold allegiance.

3. Most government-owned broadcast media will likely deny access to, or give negative attention to deviant groups and causes, especially where such groups and causes are at variance with government 
interest. On the other hand, most private broadcast media will most likely grant access to, or give objective or neutral attention to deviant groups and causes.

4. Government-owned broadcast media are likely to subordinate editorial judgement to economic pressures from government as the proprietor and sponsor. Similarity, private broadcast media may likely subordinate editorial judgment to economic pressures from the proprietors or owners, advertisers or other financial sources.

5. Where there is potential influence from financial source on content, both private and government owned media may not likely control and reveal such overture, but will most likely conceal it for reasons of continued patronage and programme sponsorship (applicable mostly to the private broadcast media) as well as for reasons of dependence or compliance (applicable mostly to the government owned media).

6. While owners of most private broadcast stations are likely to use their economic power in personally motivated and idiosyncratic way; governments as owners will most likely use their economic power on a day-to-day basis on their broadcast establishments.

7. Private broadcast media are likely to perform better than government owned broadcast media, roles as: neutral observer, transmitter and interpreter of events of significance in society - the role of public informant; participant or advocate of the masses having a purposeful influence on events: an impulse to speak up or champion the course of society's victims, minorities and underdogs; critic, adversary watchdog of any sphere of public life; and provider of platform for diverse voices of society to be heard. In other worlds, Nigerian government owned broadcast media are inclined to serving government self interest, while most private broadcast media are inclined to serving public interest.

\section{Discussions of Findings}

Findings of this study have been particularly revealing and instructive.

On question one: Is there any similarity, or difference between broadcasting operations in Nigerian before and after independence?

The study has been able to establish that similarity exists in term of government ownership of the media and the social forces that contend for attention in the broadcast media environment. The study has also revealed that variation or difference exist in terms of post independence private ownership of the broadcasting system which created two sub-systems - the government owned and private broadcasting sub-systems and which created different operational circumstances and orientations.

On the second question: What has been the nature of relationship between the Nigerian broadcast media system and forces within the broadcast media environment during the different periods of broadcasting evolution in Nigeria?

This study has been able to establish that the social forces that impact on the operations of the broadcast media system varies with the circumstances of the period and the type of government in power.

On the third question: Is there any relationship between ownership of broadcast media organisations and choice of normative responses to demand of social forces within the broadcast media environment in Nigeria?

This study has been able to establish that ownership plays an overriding influence in the operations of the broadcast media and invariably influences choice of normative responses by these media.

On the fourth question: What have been the challenges of Nigerian broadcast media organisation or operators in meeting the demands of social forces within the broadcast media environment?

This study has been able to establish that operational sustenance is a major challenge which is influenced by two major elements - ownership and advertising patronage.

\section{Conclusion and Recommendations}

Broadcasting in Nigeria has gone through a tortuous journey since inception as a colonial experience to emerge, in the present time, as a vibrant technology-driven information source. However the challenges of the dynamic social forces in the broadcast media environment that impinge on operations, creativity and potentials of media operatives should be given adequate attention, and appropriate normative responses that suit the circumstances of specific broadcast stations should be adopted. And in reference to the foregoing, this paper, based on the study's findings, therefore recommends as follows:

1. That, media organisations, particularly broadcast stations, should be adequately funded, and be allowed by the owners, public or private, to explore possible and feasible means of generating revenue through diverse programme contents and creative use of their programming.

2. Broadcast stations, particularly privately-owned, should, as far as practically, dissociate themselves from biased programming, but should rather emphasize fair and balanced programming through granting access to all shades of opinions, views, comments etc, irrespective of political, economic or social learnings. By so doing broadcast stations would be seen to be performing true to expectation, in their social roles as a neutral 
observer, participant or advocate, watchdog of any sphere of public life, a platform for the diverse voice of the society, and a responsible guardian of public order and morals.

3. To perform the above role effectively, it is also recommended that ownership factor should be considerably de-emphasised in matters of editorial policy formulations, programming contents as well as news and commentaries.

Doing all the above would not only improve the quality of broadcasting in Nigeria, but also enhance the chances of the industry in reaching the pinnacle of development from which the Nigerian society would benefit significantly.

\section{References}

[1] B. Folarin, Foundation of Broadcasting (Ibadan: Atlantis Books, 2000)

[2] R. A. Udeajah, Broadcasting and Politics in Nigeria, 1963 - 2003 (Nsukka: Mass Communication Department, University of Nigeria, Nsukka, 2005).

[3] D. McQuail, Media Performance: Mass Communication and the Public Interest (London: SAGE Publications Ltd, 1992).

[4] P. Obazele, Challenges of Radio Journalism and Management of Broadcasting in Nigeria, in O. Dare and A. Uyo (Eds.), Journalism in Nigeria: Issues and Perspectives, (Lagos: Nigerian Union of Journalism, Lagos State Chapter, 1996) 67 - 93.

[5] L.U. Uche, Mass Media, People and Politics in Nigeria, (New Delhi: Concept Publishing Company, 1989).

[6] R. A. Akinfeleye, Fourth Estate of the Realm or Fourth Estate of the Wreck: Imperatives of Social responsibility of the Press, (Lagos: University of Lagos Press, 2003).

[7] S. Enemaku, The Deregulation of the Nigerian Broadcast Industry and the Ensuing Challenges and Opportunities, in R. A. Akinfeleye and I. Okoye, (Eds), Issues in Nigerian Media History 1960 - 2000AD, (Lagos: Malthouse Press Limited, 2003 ) 47 - 61. 